\title{
Phospholipases $A_{2}$ from Callosellasma rhodostoma venom gland Cloning and sequencing of 10 of the cDNAs, three-dimensional modelling and chemical modification of the major isozyme
}

\author{
Inn-Ho Tsai ${ }^{1,2}$, Ying-Ming Wang', Lo-Chun $\mathrm{Au}^{3}$, Tzu-Ping Ko', Yi-Hsuan Chen ${ }^{1}$ and Yi-Fang Chu ${ }^{2}$ \\ ${ }^{1}$ Institute of Biological Chemistry, Academia Sinica, Taipei, Taiwan; ${ }^{2}$ Institute of Biochemical Science, National Taiwan University, \\ Taipei, Taiwan; ${ }^{3}$ Department of Medical Research, Veterans General Hospital-Taipei, Taiwan,
}

\begin{abstract}
Callosellasma rhodostoma (Malayan pitviper) is a monotypic Asian pitviper of medical importance. Three acidic phospholipases $\mathrm{A}_{2}\left(\mathrm{PLA}_{2} \mathrm{~s}\right)$ and one basic PLA $\mathrm{A}_{2}$-homolog were purified from its venom while $10 \mathrm{cDNAs}$ encoding distinct $\mathrm{PLA}_{2} \mathrm{~S}$ were cloned from venom glands of a Thailand specimen of this species. Complete amino-acid sequences of the purified $\mathrm{PLA}_{2} \mathrm{~S}$ were successfully deduced from their cDNA sequences. Among the six un-translated PLA $\mathrm{C}_{2}$ cDNAs, two apparently result from recombination of its Lys49-PLA 2 gene with its Asp49-PLA 2 genes. The acidic $\mathrm{PLA}_{2}$ s inhibit platelet-aggregation, while the noncatalytic PLA $_{2}$-homolog induces local edema. This basic PLA 2 -homolog contains both Asp49 and other, unusual substitutions unique for the venom Lys49-PLA 2 subtype (e.g. Leu5, Trp6, Asn28 and Arg34). Three-dimensional modelling of the basic protein revealed a heparin-binding region, and an abnormal calcium-binding pocket, which may explain its low catalytic activity. Oxidation of up to six of its Met residues or coinjection with heparin reduced its edemainducing activity but methylation of its active site His48 did not. The distinct Arg/Lys-rich and Met-rich region at positions $10-36$ of the $\mathrm{PLA}_{2}$ homolog presumably are involved in its heparin-binding and the cell membraneinterference leading to edema and myotoxicity.
\end{abstract}

Keywords: phospholipase $\mathrm{A}_{2}$; cDNA sequences; modelling; edema; Malayan pitviper.

Calloselasma rhodostoma (Malayan pitviper) is the commonest cause of snakebites in Malaysia and Thailand. The venom causes local effects and systemic bleeding. Its venom has been reported to contain moderate to low levels of phospholipases $A_{2}$ (PLA ${ }_{2}$, E.C.3.1.1.4) [1]. However, the structure and activity of the venom $\mathrm{PLA}_{2} \mathrm{~S}$ of this primitive monotypic pitviper were not known [2]. As one of the commonest viperid venom components, the $\mathrm{PLA}_{2} \mathrm{~s}$ usually exist in multiple isoforms, which show distinct pharmacological effects such as neurotoxicity, myotoxicity, edema induction, anti-platelet or anticoagulating activities $[3,4]$. These isoforms are the results of gene duplication and accelerated evolution and have acquired functional diversity [5]. $\mathrm{Ca}^{2+}$ ion plays an essential role in the catalytic mechanism of the enzyme, however, some of the venom $\mathrm{PLA}_{2} \mathrm{~S}$ have substitution such as Lys49 at the $\mathrm{Ca}^{2+}$ binding site (Asp49) and evolved into toxins independent of phospholipid-hydrolysis to exert their functions [4].

Correspondence to I.-H. Tsai, PO Box 23-106, Taipei, Taiwan 10798.

Fax: + 8862 23635038, E-mail: bc201@gate.sinica.edu.tw

Abbreviations: CRV, Callosellasma rhodostoma venom; ESI-MS,

electrospray ionization mass; NCS, $N$-chlorosuccinimide; NOB,

4-nitro-3-(octanoyloxy)benzoic acid; $\mathrm{PLA}_{2}$, phospholipase $\mathrm{A}_{2}$; $\mathrm{diC}_{16} P C h o$, dipalmitoyl-glycerophosphocholine .

Enzyme: phospholipase $\mathrm{A}_{2}$ (E.C.3.1.1.4).

Note: the novel nucleotide sequences for the C. rhodostoma $\mathrm{PLA}_{2} \mathrm{~s}$ have been submitted to the EMBL databank and are available under accession nos: AF104066 (for K49), AF104073 (for W6hybrid), AF104065 (for W6D49), AF10406870 (for S1E6a-c), AF104067 (for H1E6), AF104071-2 (for R6a-b) and AF104074 (for R6K49), respectively.

(Received 19 June 2000, revised 12 September 2000, accepted

14 September 2000)
Asia is known as the original and the major habitat for present day pitvipers. C. rhodostoma is a primitive monotypic species which contain venom proteins distinct from those of other Asian pitvipers, e.g. its zinc-metalloprotease has been found to have special structure [6]. Thus, characterization of the $\mathrm{PLA}_{2} \mathrm{~S}$ of this venom species at gene and protein levels would presumably significantly enhance our knowledge about the evolution of the venom $\mathrm{PLA}_{2} \mathrm{~S}$ and the Asian pitvipers.

In the present study, we cloned at least 10 different $\mathrm{PLA}_{2} \mathrm{~S}$ from the venom gland cDNA library of $C$. rhodostoma. Complete sequences of the purified venom $\mathrm{PLA}_{2} \mathrm{~S}$ were inferred by matching their partial amino-acid sequences and masses against the cDNA-deduced sequences. The major PLA $\mathrm{P}_{2}$ of this venom, designated as CRV-W6D49 because of its Trp6 and Asp49 substitutions, was a novel type of basic PLA Phomolog $_{2}$ without detectable hydrolytic activities. Heparin may bind this protein and inhibit its edema-inducing activity. Its 3D structure was predicted by homologous modelling and the abnormal active site was examined. Possible involvement of its exposed methionine residues in the edema-inducing effect was studied by the modification using $\mathrm{N}$-chlorosuccinimide.

\section{MATERIALS AND METHODS}

\section{Materials}

Venom glands from a single specimen and pooled venom of $C$. rhodostoma were from the Thai Red-Cross Society (Bangkok). Dipalmitoyl-glycerophosphocholine ( $\left.\mathrm{diC}_{16} \mathrm{PCho}\right)$ powder was purchased from Avanti Polar labs. Methyl $p$-nitrobenzenesulfonate was a product of Aldrich. Bovine serum albumin, heparin, $\mathrm{N}$-acetyl-methionine, $\mathrm{N}$-chlorosuccinimide, sodium 
deoxycholate, and Triton X-100 were purchased from Sigma Chemical. 4-Nitro-3-(octanoyloxy)benzoic acid (NOB) is a gift from F. J. Ketzdy (The Upjohn Company, Kalamazoo, MI, USA) [7] and is now available from Sigma. Other reagents and buffers are of reagent grade.

\section{Purification of PLA}

The crude venom of $C$. rhodostoma (10-15 mg) was fractionated on a Superdex G-75 column (HR 10/30, Pharmacia, Sweden) in $0.1 \mathrm{M}$ ammonium acetate $(\mathrm{pH} 4.2)$, at room temperature. Fractions containing proteins of 14 and $26 \pm 2 \mathrm{kDa}$ were pooled separately and lyophilized. $\mathrm{PLA}_{2} \mathrm{~S}$ of the venom were further purified by RP-HPLC using a column of C8-silica gel (Vydac, $14 \times 250 \mathrm{~mm}, 10 \mu$ ) equilibrated with $0.07 \%$ aqueous trifluoroacetic acid. The enzymes were eluted with a $28-50 \%$ linear gradient of $\mathrm{CH}_{3} \mathrm{CN}$ containing $0.07 \%$ trifluoroacetic acid. The HPLC conditions usually do not have an adverse effect on the $\mathrm{PLA}_{2}$ activities. The $\mathrm{PLA}_{2}$ peaks were identified and dried in a vacuumcentrifuge device (Labconco).

\section{Mass spectrometry and partial sequencing of purified $\mathrm{PLA}_{2} \mathrm{~S}$}

The molecular masses of $\mathrm{PLA}_{2} \mathrm{~S}$ were determined by electrospray-ionization mass spectrometry (ESI-MS) using a PE-Sciex API100 mass analyzer (PerkinElmer). Samples were dissolved in $20 \mu \mathrm{L}$ of $50 \% \quad \mathrm{CH}_{3} \mathrm{CN}$ containing $0.1 \%$ acetic acid and injected into the analyzer for positive-mode analysis. The $\mathrm{N}$-terminal amino-acid sequences of proteins were determined by a gas-phase sequencer (model 477A, Applied Biosystems) with an on-line phenylthiohydantoin amino-acid analyzer using the NORMAL program [8].

\section{Protein quantitation and enzyme assay}

The dye-staining method of Bradford was used for quantification of the purified $\mathrm{PLA}_{2}$ in solution. BSA $\left(1 \mathrm{mg} \cdot \mathrm{mL}^{-1}\right.$, $A_{280}=0.56$ ) was used to establish the standard curve [9]. PLA activity was measured by $\mathrm{pH}$-stat titration at $\mathrm{pH} 7.4$ and $37{ }^{\circ} \mathrm{C}$. Fresh egg yolk $(2.5 \mathrm{~g})$ was dissolved in $100 \mathrm{~mL} 0.10 \mathrm{M} \mathrm{NaCl}$ and mixed thoroughly. Alternatively, $\operatorname{diC}_{16} P C h o(3 \mathrm{~mm})$ was mixed with $3 \mathrm{~mm}$ sodium deoxycholate or $6 \mathrm{~mm}$ Triton X-100 and $100 \mathrm{~mm} \mathrm{NaCl}$ in a glass-Teflon tissue homogenizer to form micelles. With constant stirring, $10 \mathrm{~mm} \mathrm{CaCl}_{2}$ was added just before addition of the enzyme to the thermostated substrate [10]. The liberated fatty acid was titrated with $6 \mathrm{~mm} \mathrm{NaOH}$ using a pH-stat apparatus (Radiometer RTS822, Denmark). The reaction rate was corrected for the nonenzymatic rate. Indirect and direct hemolysis of red blood cells by CRV-W6D49 were performed as described [11] to detect the hydrolase activity towards natural membrane bilayer. The esterase activity towards NOB in Tris buffer ( $\mathrm{pH} 7.4$ ) with $10 \mathrm{~mm} \mathrm{CaCl}_{2}$ was followed spectrophotometrically at $400 \mathrm{~nm}$ [7].

\section{Cloning and nucleotide sequencing}

The cDNA library of $C$. rhodostoma venom gland was constructed by Au et al. [12]. In order to amplify the PLA $\mathrm{P}_{2}$ cDNA, PCR was carried out using the cDNA library as the template. A pair of degenerate oligonucleotide primers, with 21 and 18 mixed-base, respectively, were designed based on the highly conserved $5^{\prime}$ and $3^{\prime}$ regions in cDNA of other known group-II snake venom $\mathrm{PLA}_{2} \mathrm{~S}$ [10]. The PCR procedure was performed with SuperTaq DNA polymerase. A $0.4-\mathrm{kb}$ fragment was specifically amplified as shown by $1 \%$ agarose gel electrophoresis. After treatment with polynucleotide kinase, the amplified DNA was inserted into the pGEM-T vector (Promega Biotech) and then transformed into Escherichia coli strain JM109. White transformants were picked-up and their DNA extracted and selected by examination of its restriction enzyme products under agarose gel electrophoresis.

The DNA Sequencing System model 373A and the Taq DyeDeoxy terminator cycle sequencing kit (PE Applied Biosystems) were used to determine the cDNA sequences of more than 80 clones obtained in this study [13].

\section{Modification of CRV-W6D49}

CRV-W6D49 was oxidized with $N$-chlorosuccinimide (NCS) which selectively converts methionine residues into methionine sulfoxide derivatives $[14,15]$. The modification of CRV-W6D49 was in $0.1 \mathrm{M}$ sodium borate $(\mathrm{pH} \mathrm{8.5)}$ at room temperature $\left(18{ }^{\circ} \mathrm{C}\right)$. The protein concentration was $75 \mu \mathrm{M}$ throughout and the NCS concentration was 10 -fold that of the protein. After reacted for $1 \mathrm{~h}$, excess $N$-acetyl methionine was added to halt the reaction. The modified proteins were then purified by RP-HPLC and dried in vacuum. Molecular masses of the oxidized proteins were analyzed by ES1-MS to find out the extent of oxidation. Methylation of the imidazole group or the only His residue (His48) in CRV-W6D49 with methyl $p$-nitrobenzenesulfonate was carried out by the methods of Verheij et al. [16].

\section{Circular dichroism}

CD measurements were carried out on a J715 spectropolarimeter (Jasco, Japan) under constant flushing of nitrogen at $25^{\circ} \mathrm{C}$. Each sample was scanned from 200 to $250 \mathrm{~nm}$ for two or three times and superimposable spectra were obtained. The mean residue elipticity $[\theta]$ was calculated from the mean residue weight.

\section{Binding of PLA $A_{2}$ to heparin and its effect on edema-induction}

Relative affinity of the basic $\mathrm{PLA}_{2}$ for binding to heparin was studied using a HiTrap heparin column (5 mL, Pharmacia Co.) on an FPLC apparatus [17]. The hind-paw edema of a rat (female Wistar, 200-250 g) was measured with a plethysmometer (Ugo Basile, model 7150). Extent of hind-paw swelling was calculated based on the paw volume after the injection with native or chemically modified $\mathrm{PLA}_{2}$ in contrast to buffer injected in the control experiment [18].

\section{Platelet inhibition by the acidic PLA $\mathrm{S}_{2}$}

Fresh blood was obtained by bleeding the white rabbits through the ear-vein, and the platelet-rich plasma was prepared. The effect of the venom $\mathrm{PLA}_{2}$ on the ADP-induced platelet aggregation was studied on an aggregometer (Payton, module 600B, Canada) [18].

\section{Computer modelling of the basic PLA}

The atomic coordinates of K49-PLA 2 from Bothrops venom were obtained from the Protein Data Bank (PDB accession no. 1GOD). The amino-acid sequence differs from CRV-W6D49 by 46 residues. These were replaced using the program o [19] and conformations of the substituted side-chains were also adjusted. To assess proper side-chain orientation, another K49-PLA 2 structure from Agkistrodon p. picivorus [20] (PDB accession 
no. 1PPA) was superimposed on the working model for reference. There are 19 other crystal structures of $\mathrm{PLA}_{2}$ that have been refined to higher than $2.0 \AA$ resolution, although 15 of these are the $\mathrm{PLA}_{2} \mathrm{~S}$ from bovine pancreas. These 3D structures were also superimposed on and compared with the working model to provide additional reference for adjustments. The model was subjected to molecular dynamic (MD) and energy minimization (EMin) using XPLOR [21]. The temperature started at $500 \mathrm{~K}$ and increased to $800 \mathrm{~K}$, then decreased in 10 - to $25-\mathrm{K}$ steps to $300 \mathrm{~K}$. The model coordinates were restrained by harmonic coefficients to the original in the course of MD but were allowed to shift unrestrained in EMin. The best models were selected using stereochemical criteria as evaluated using PROCHECK [22], and were used for next cycles of MD and EMin.

\section{RESULTS AND DISCUSSION}

\section{cDNA cloning and nucleotide sequencing}

By sequencing more than 80 clones from the C. rhodostoma venom gland cDNA library we identified the clones encoding 10 distinct $\mathrm{PLA}_{2} \mathrm{~s}$. More than $50 \%$ of the clones obtained were found to encode CRV-W6D49. Only the $\mathrm{PLA}_{2} \mathrm{~s}$ that have been cloned repetitively and their cDNA nucleotide sequences confirmed at least twice were reported herein. The signal peptides of 16 residues are almost identical or differed by less than three semiconserved residues in these $\mathrm{PLA}_{2}$ precursors (data not shown). Their protein sequences were deduced from the nucleotide sequences and aligned in Fig. 1. The isoelectric points were predicted from their sequences, CRV-H1E6, S1E6 $(\mathrm{a}-\mathrm{c})$ and R6 are acidic $\mathrm{PLA}_{2} \mathrm{~s}$, W6D49 and K49 are basic $\mathrm{PLA}_{2}$ homologs, while the basic W6-hybrid and R6K49 are of hybrid types as their names imply.

\section{Purification and characterization of $\mathrm{PLA}_{2} \mathrm{~S}$}

Gel filtration of the crude venom of $C$. rhodostoma using a Superdex G75 FPLC column separated the monomeric PLA $\mathrm{S}_{2} \mathrm{~S}$ from the dimeric $\mathrm{PLA}_{2} \mathrm{~S}$ [2]. Using the $26-\mathrm{kDa}$ fraction obtained from the gel-filtration three dimeric $\mathrm{PLA}_{2}$ showing high hydrolytic activities toward lecithin substrates were purified by HPLC. They were designated as CRV-H1E6, S1E6a and b, respectively (Fig. 2A). Content for each of these acidic $\mathrm{PLA}_{2} \mathrm{~S}$ was estimated to be about $1-2 \%$ (mass/ mass) of the total venom proteins. Their masses (Fig. 2B) are in consistent with those calculated from the cDNA-deduced sequences (Fig. 1) and they inhibited the aggregation of rabbit platelets induced by ADP.

On the other hand, a basic $\mathrm{PLA}_{2}$ homolog (designated as CRV-W6D49) was purified from the 14-kDa fraction of gel filtration with a yield of about $4 \%$ (mass/mass) (Fig. 2A). This basic protein with realtive molecular mass of 13674 shows no detectable enzyme activities toward egg yolk or the micellar
1. CRV-S1E6a
2. $\mathrm{CRV}-\mathrm{S} 1 \mathrm{E} 6 \mathrm{~b}$
3. $C R V-S 1 E 6 C$
4. $\mathrm{CRV}-\mathrm{H} 1 \mathrm{E} 6$
5. $\mathrm{CRV}-\mathrm{R} 6 \mathrm{a}$
6. $C R V-R 6 b$
7. $\mathrm{CRV}-\mathrm{W} 6 \mathrm{D} 49$
8. $\mathrm{CRV} / \mathrm{TMV} / \mathrm{DAV}-\mathrm{K} 49$
9. CRV-W6-HYBRID
10. $\mathrm{CRV}-\mathrm{R} 6 \mathrm{~K} 49$

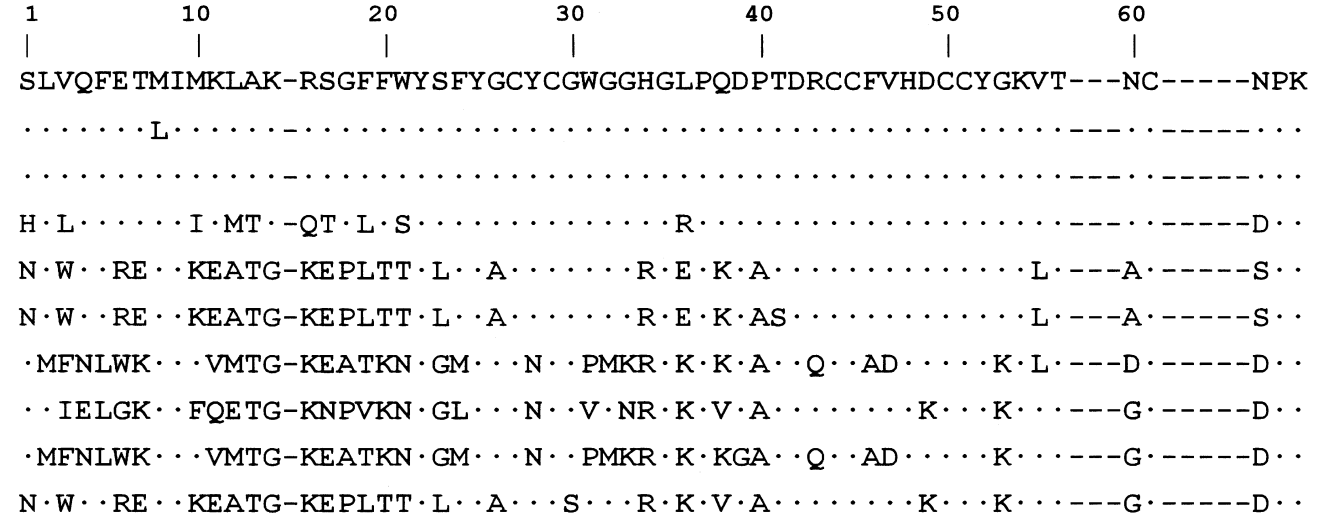

$\mathrm{N} \cdot \mathrm{W} \cdot \mathrm{RE} \cdot \mathrm{KEATG-KEPLTT} \cdot \mathrm{L} \cdot \mathrm{A} \cdots \mathrm{S} \cdots \mathrm{R} \cdot \mathrm{K} \cdot \mathrm{V} \cdot \mathrm{A} \cdots \mathrm{K} \cdot \mathrm{K} \cdots \mathrm{K} \cdots--\mathrm{G} \cdot----\mathrm{D} \cdot$

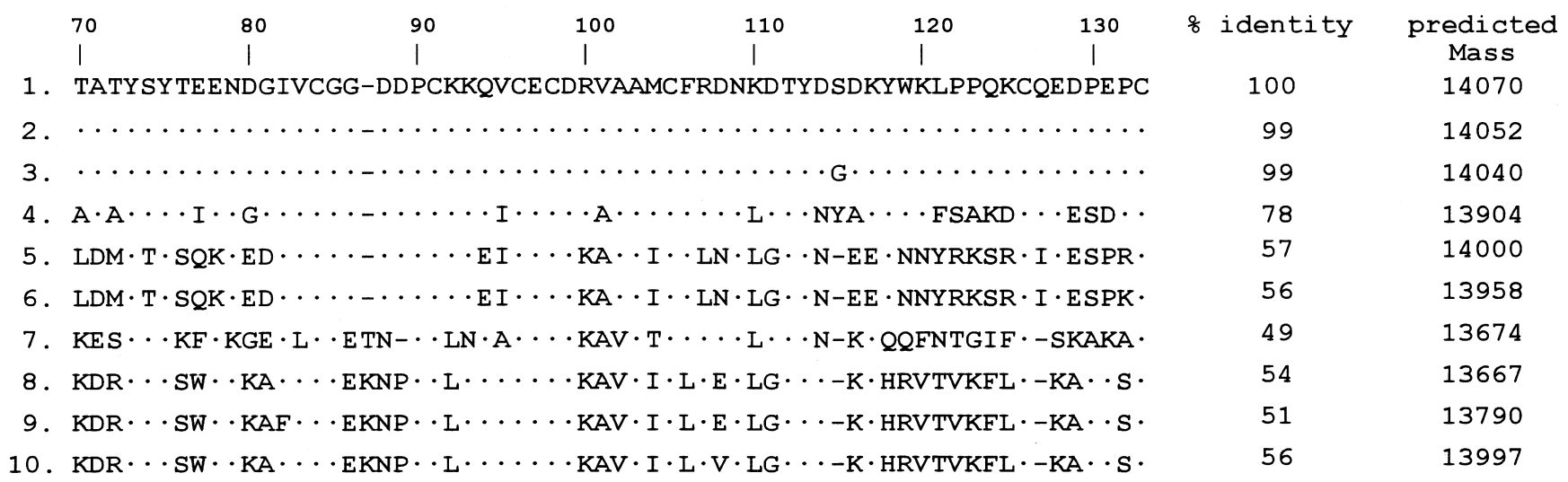

Fig. 1. Amino-acid sequences and molecular masses of venom $\mathrm{PLA}_{2} \mathrm{~s}$ deduced from the nucleotide sequences of 10 cDNA clones of $C$. rhodostoma. The protein sequences were deduced from the nucleotide sequences of $\mathrm{PLA}_{2}$-cDNAs from the venom gland. Single-letter codes of amino acids were used, the numbering system follows that of Renetseder et al. [24]. Residues identical to those in the top line is denoted with a dot; gaps are marked with hyphens. Abbreviations are: TMV, T. mucrosquamatus venom and DAV, D. acutus venom [29]. 
substrates containing synthetic $\operatorname{diC}_{16} P C h o$ [2]. To test whether it may hydrolyze the phospholipids in model cell membranes, red cell ghosts were prepared from the washed human erythrocytes by hypotonic lysis [23] and incubated with $20 \mu \mathrm{g} \cdot \mathrm{mL}^{-1}$ of CRV-W6D49 in Tris buffer (pH 7.4) at $37{ }^{\circ} \mathrm{C}$ for $6 \mathrm{~h}$. Then the ghosts and the venom protein were added to intact erythrocytes and the rate of hemolysis was followed. We found hardly any direct and indirect hemolysis [11] by CRV-W6D49 in the presence of $\mathrm{Ca}^{2+}$, while a control experiment using CRV-S1E6a show prominent indirect hemolysis. The results suggested that CRV-W6D49 could not generate lysophospholipid from leaky cell membrane or the unsealed ghosts unlike normal $\mathrm{PLA}_{2} \mathrm{~s}$.

It is unusual that a D49-PLA 2 from pitviper venom does not show enzymatic activities in vitro using either egg yolk, the micellar dipalmitoyl lecithin, or the ghosts as the substrates (see above). As some of these assays contain phospholipids with various head-groups and different fatty-acyl chains, CRV-W6D49 apparently does not behave like a phospholipase enzyme by definition. Although the protein appears to have a very low activity towards a pseudo-substrate, NOB, in the presence of $\mathrm{Ca}^{2+}$ [7], this may merely reflect an insufficient catalytic apparatus in CRV-W6D49. Furthermore, when active site His48 of CRV-W6D49 was methylated with methyl $p$-nitrobenzenesulfonate [16], the relative molecular mass was increased to 13686 as expected, and the derivative was found to retain the edema-inducing potency of the native form (data not shown). Thus, the results suggest that His48 or an intact catalytic site is not required for the in vivo edematous effect of CRV-W6D49.

Results of ESI-MS of the purified venom proteins show the presence of minor forms of CRV-W6D49 and CRV-S1E6a (Fig. 2B), each with a molecular mass higher than the respective major form by 16 . As both proteins contain methionine residues, the minor forms may be oxidation products occurring during venom storage or purification rather than products of limited hydrolysis as only one $\mathrm{N}$-terminus was detected during the protein sequencing.

\section{Distinctness of venom $\mathrm{PLA}_{2} \mathrm{~S}$ of $\mathrm{C}$. rhodostoma}

It has been hypothesized that Glu6, Asp114, and four aromatic residues at positions 20,21, 113 and 119 at the surface of Crotaline venom acidic $\mathrm{PLA}_{2} \mathrm{~S}$ are associated with their antiplatelet effects [24]. These sites are also conserved in the purified acidic $\mathrm{PLA}_{2}$ s from C. rhodostoma venom (Fig. 1). However, we noticed that some common residues in other acidic $\mathrm{PLA}_{2} \mathrm{~s}$ of Crotaline venom, namely Ala40, Gly60, Ser76, Gly80, Ile104 and Asn125, have been substituted in the acidic C. rhodostoma $\mathrm{PLA}_{2} \mathrm{~s}$.

The deduced amino-acid sequence of CRV-W6D49 with theoretical pI of 8.3 is $75 \%$ similar to those of the K49-PLA $2 \mathrm{~S}$ (usually with pI of 8.8-9.5) from various pitviper venoms but only $<60 \%$ identical to the other D49-PLA 2 s from the same venom (Fig. 1). Notably, CRV-W6D49 contains unusual substitutions, e.g. Met2, Asn4, Val11, Pro31, Gly32M, Gly33K and Gly53K and Trp6, Leu5, Lys7, Asn28, Pro31, Val102, Lys53, Glu86 which are uniquely conserved in the venom K49 $\mathrm{PLA}_{2} \mathrm{~S}$ [25-29]. These substitutions together may be responsible for its low catalytic activity and $\mathrm{Ca}^{2+}$-independent myotoxicity and edema-inducing activities. Notably, CRV-W6D49 (Fig. 1) shares with $\mathrm{K} 49 \mathrm{PLA}_{2} \mathrm{~s}$ the proposed myotoxic sites involving Thr13 and Lys residues 7, 16, 78, 79 or 80, 116 and 117 [26,27]. Thus, CRV-W6D49 and K49 PLA 2 s share structural and functional similarities.
Fig. 2. Purification and ESI-MS analyses of venom PLA 2 s. (A) Fractions I and II (Fig. 1) from gel filtration were further purified by RP-HPLC on a C8 silica gel column. The peaks corresponding to a monomeric basic $\mathrm{PLA}_{2}$ (CRV-W6D49, i.e. W6) and three dimeric acidic $\mathrm{PLA}_{2}$ s (CRV-H1E6, S1E6a and S1E6b) were denoted with arrows, respectively. (B) Molecular masses of the purified $\mathrm{PLA}_{2} \mathrm{~S}$ as determined by ESI-MS.

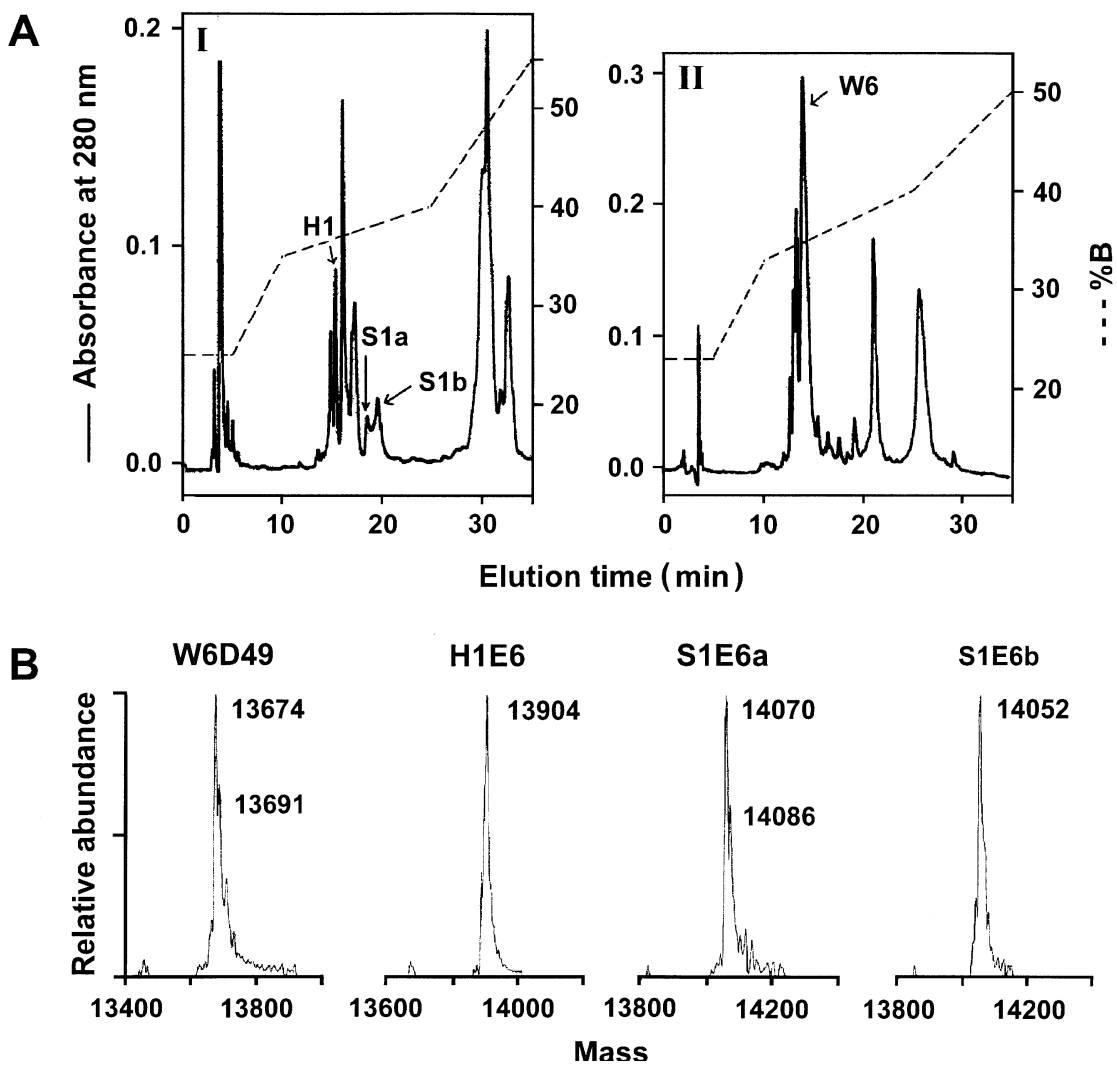




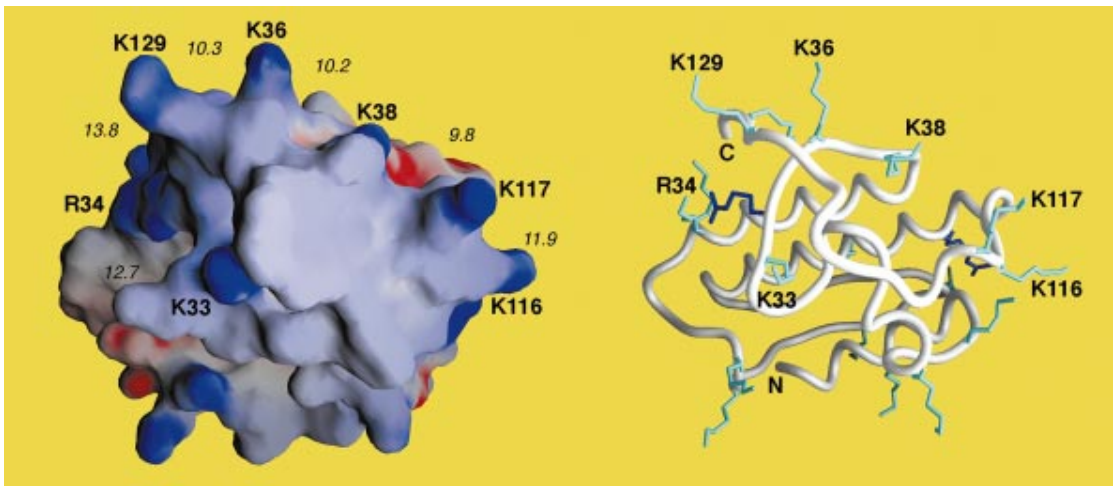

Fig. 3. Backbone structure and molecular surface of the CRV-W6D49 model. (Right) Backbone tracing of the CRV-W6D49 3D model in which the $\mathrm{N}$ - and $\mathrm{C}$-termini are indicated. Also shown are the side-chains of all positively charged residues, arginines in blue and lysines in cyan. (Left) Electrostatic potential with range of -10 to $+10 \mathrm{k}_{\mathrm{B}} \mathrm{T}$ is shown (blue for positive and red for negative charge as calculated by GRASP) [38]. The view is in the direction of putative heparin-binding site and residues speculated to interact with the heparin are labelled. Numbers in italic are the distances in $\AA$ between the nearest positively charged side-chains.

\section{Effect of heparin on the function of basic $\mathrm{PLA}_{2}$ homolog}

CRV-W6D49 also contains a potential heparin-binding motif of multiple positive charges [17] at residues 33-36, which is flanked by Pro31 and Pro37 forming a proline-bracket [30] (Fig. 1). In K49 $\mathrm{PLA}_{2} \mathrm{~S}$, heparin-binding motifs are located in the C-terminal region 115-119 [27,28], which is in fact not far from region 33-36 in the 3D structures or models of these

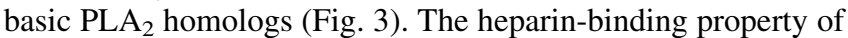
CRV-W6D49 was experimentally shown by their strong adsorption to a heparin-column and elution off the column at a salt concentration above $0.4 \mathrm{M} \mathrm{NaCl}$ (data not shown) [17]. By incubating CRV-W6D49 with various concentration of heparin before injection into the paws, the edema was greatly reduced by heparin in a dose-dependent manner (data not shown).

\section{Untranslated PLA 2 mRNAs}

Polymorphic $\mathrm{PLA}_{2}$ genes and mRNAs are usually found in snake venom glands [25]. Six of the 10 C. rhodostoma $\mathrm{PLA}_{2}$ clones are apparently not translated into venom proteins. Some of them possibly represent spare or regressed genes with a potential to be expressed through the snake natural history. The retention of low-expressing mRNA of venom proteins may be beneficial for snake survival under ever-changing environment. Interestingly, two of the untranslated $\mathrm{PLA}_{2} \mathrm{~s}, \mathrm{CRV}-\mathrm{K} 49$ and CRV-R6 (Fig. 1), are structurally almost identical to the abundantly expressed K49-PLA ${ }_{2}$ [18] and $\mathrm{PLA}_{2}$ III in Trimeresurus mucrosquamatus venom, respectively (GenBank accession no. X77088). This finding also supports the functional significance of both $\mathrm{PLA}_{2}$ genes.

Two of the untranslated clones obtained in this study apparently encode hybrid types of $\mathrm{PLA}_{2} \mathrm{~s}$, which we designated as CRV-W6-hybrid and CRV-R6K49, respectively (Fig. 1). Both $\mathrm{PLA}_{2}$ hybrids have a C-terminal sequence highly similar to that of CRV-K49 $\mathrm{PLA}_{2}$ while the N-terminal part of CRV-W6-hybrid is almost identical to CRV-W6D49 and that of CRV-R6K49 is similar to CRV-R6. Hybrid types of PLA mRNAs were also recently found in the venom glands of Agkistrodon halys Pallas [31,32] and Deinagkistrodon acutus [33]. However, hybrid proteins were not isolated in any of the crude venoms, suggesting that they probably are pseudogenes. Notably, most of the recombination or crossing-over apparently occurred at a highly conserved region near an intron-exon junction encoding amino-acid residues $42-48$ of the $\mathrm{PLA}_{2} \mathrm{~s}$ [34].

\section{Computer modelling and structure-activity relationship}

The 3D model of CRV-W6D49 PLA 2 is shown in Fig. 3, and contains 943 nonhydrogen atoms in 122 amino-acid residues, showing excellent geometry with rmsd of $0.003 \AA$ in bond lengths and $0.446^{\circ}$ in bond angles. The distribution of peptide dihedral angles was also improved for this model in which $85.0 \%$ of nonglycine and nonproline residues are in the most favored region compared with only $76.6 \%$ for the initial model of the K49 $\mathrm{PLA}_{2}$ structure. All of the remaining residues were also found in the allowed regions. The overall coordinate difference between the initial and final models is low, with rmsd of $0.35 \AA$ in coordinates for backbone atoms and $1.16 \AA$ for the side-chains. Beside the altered regions near residues Met32 and Glu86, maximal deviation in backbone atoms occurred in regions near the C-terminus. Specifically, the peptides Thr 121-Gly 122 and Cys126-Ser127 became more similar to those of bovine pancreatic $\mathrm{PLA}_{2}$ and Agkistrodon K49-PLA 2 [20], respectively.

Presumably the binding sites for sulfated aminoglycan contains clusters of positively charges, as shown in the surface-potential map of the model (Fig. 3). The distances between the positively charged residues range between 9.8 and $13.8 \mathrm{~A}$, which probably play essential roles in the binding of CRV-W6D49 to heparin or heparan sulfate [35].

The N-terminal region of CRV-W6D49 is exceptionally rich in Met-residues (at positions 2, 8, 10, 12, 24 and 32). It has been shown that surface Met cluster may serve as a flexible and

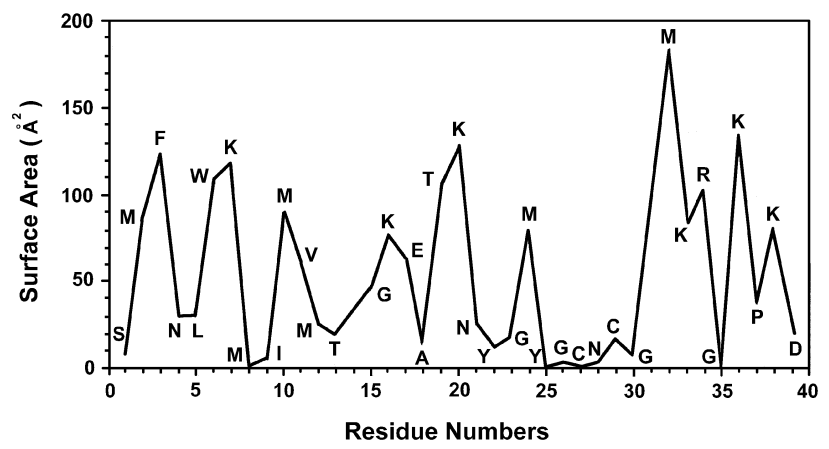

Fig. 4. Accessible surface area of the N-terminal region in CRV-W6D49 model. The exposed areas for residues $1-35$ of the CRV-W6D49 model were calculated using program AREAIMOL of the CCP4 Suite (Collaboration Computational Project [37]) and plotted. Single-letter codes of amino acids are used. 


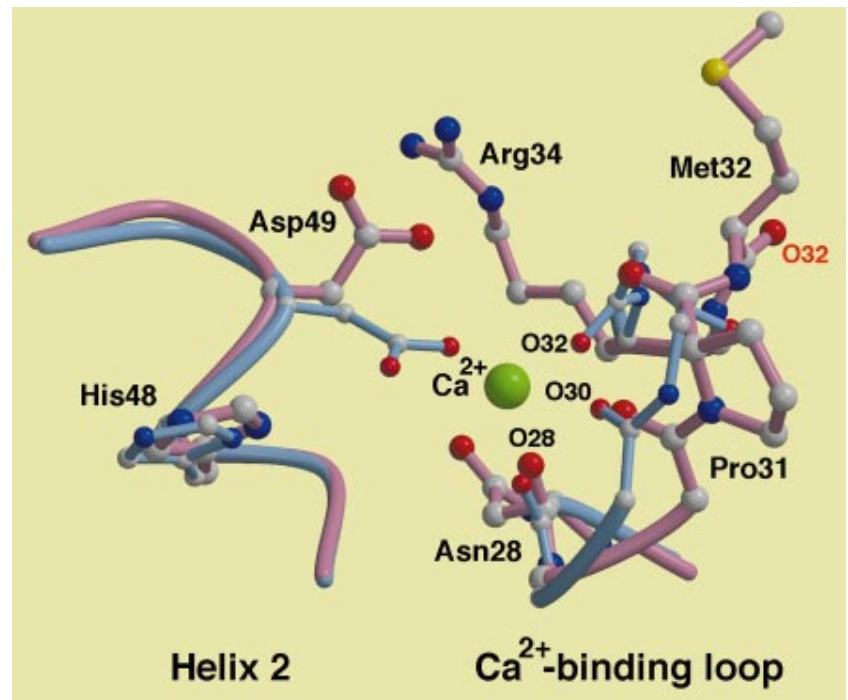

Fig. 5. Structure of $\mathrm{Ca}^{2+}$-binding region of the CRV-W6D49 model. The model of the active site of CRV-W6D49 is shown in pink and that of an active $\mathrm{PLA}_{2}$ from Taiwan cobra venom (PDB accession no. 1POA) is in blue. Selected residues in our model are labeled with its position number. The calcium ion is shown in green and the three back-bone oxygens that bind the $\mathrm{Ca}^{2+}$ ion in the active PLA $\mathrm{A}_{2}$ are also labeled. The carbonyl oxygen of Met 32, labeled in red, was moved $5 \AA$ further away from the position for calcium binding. This figure was produced using MOLSCRIPT [39] and RASTER3D [40].

efficient hydrophobic protein-protein interacting site [36]. The local solvent accessibilities of the Met residues were thus analyzed and Met2, Met10, Met24 and Met32 are found to be exposed (Fig. 4).

Figure 5 shows the active site of the CRV-W6D49 model in comparison with that of an ordinary D49-PLA2 from cobra venom. In the normal active site the catalytic calcium is coordinated by seven ligands, two from the carboxyl oxygens of Asp49 side-chain, three from the backbone carbonyl oxygens of residues 28, 30 and 32, and two water molecules [20,24]. Our model shows that only the CO groups of Asn28 and Gly30 are maintained in the calcium binding position of CRV-W6D49. The distances are 2.36 and $2.68 \mathrm{~A}$ from the metal ion, respectively, while the latter is not short enough to make proper bonding interaction. The third $\mathrm{CO}$ group of our model assumes a completely different arrangement from the corresponding residue Gly32 in the active enzyme. Due to the flipping over of peptide Pro31-Met32, the carbonyl oxygen of Met32 was moved $4.98 \AA$ farther away from the calcium. The distance is about $7.2 \AA$, unable to interact with the metal ion. The $\mathrm{Ca}^{2+}$-binding loop seems no longer effective in CRV-W6D49. Notably, Arg34 in the active site of CRVW6D49 probably form a stable salt bridge with Asp 49 whose acidic side-chain is rotated $120 \AA$ (Fig. 5). This is possibly the reason why CRV-W6D49 does not bind calcium.

\section{Effect of oxidation on the edematous potency of CRV-W6D49}

Methionine residues of CRV-W6D49 were modified by NCS in a mild alkaline solution, resultant derivatives were purified by RP-HPLC (Fig. 6). Because the higher degree of Met oxidation in the protein, the less hydrophobic the protein became, the modified CRV-W6D49 was eluted from the column followed the order of derivatives of $(\mathrm{MetO})_{6},(\mathrm{MetO})_{5}$ and $(\mathrm{MetO})_{4}$, and the native protein, as verified by the ESI-MS results (Fig. 6).
The conformation of CRV-W6D49 was apparently altered by the modification as revealed by the CD spectra (Fig. 7). As 51 among its total 122 residues are located in helices according to the 3D model (Fig. 3), the helical content for native CRVW6D49 is postulated to be $42 \%$. Based on the CD spectra, the helical content for the native, the $(\mathrm{MetO})_{4}$ and the $(\mathrm{MetO})_{6}$ derivatives of CRV-W6D49 were calculated to be 41, 31 and $25 \%$, respectively. The $\beta$-structures were increased by the modification, while portions of random structures were kept relatively constant $(35 \pm 1 \%)$. Met2, Met8 and Met12 are present in $\alpha$-helix $1-12$ of the native $\mathrm{PLA}_{2}$ and Met24 is at the end of $\alpha$-helix 18-22. Oxidation of these Met residues probably loosened the N-terminal helix of the protein. Oxidation of

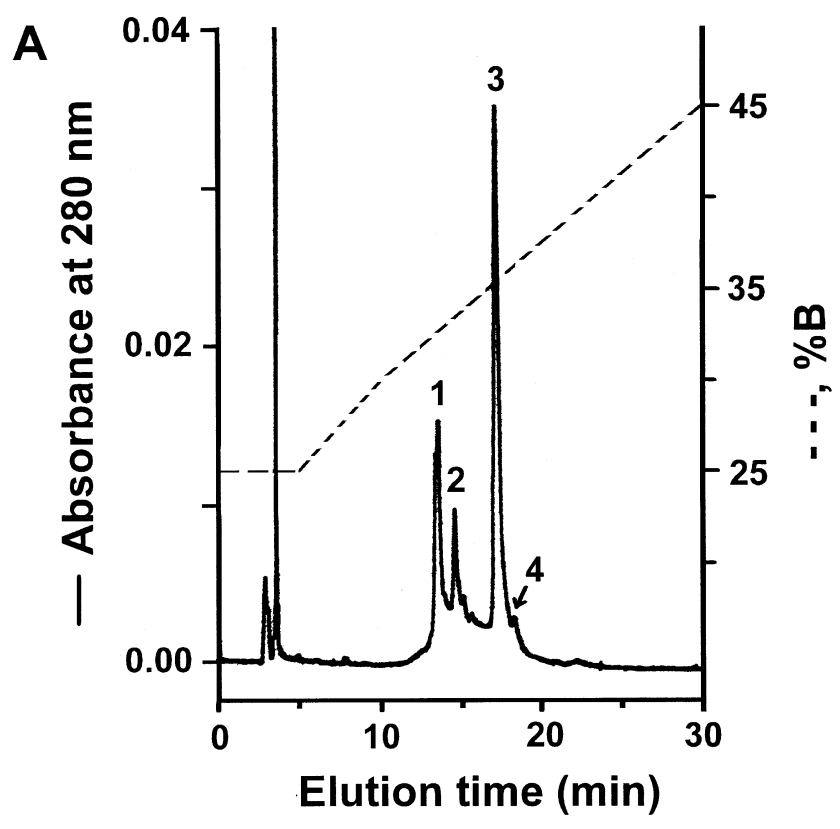

B

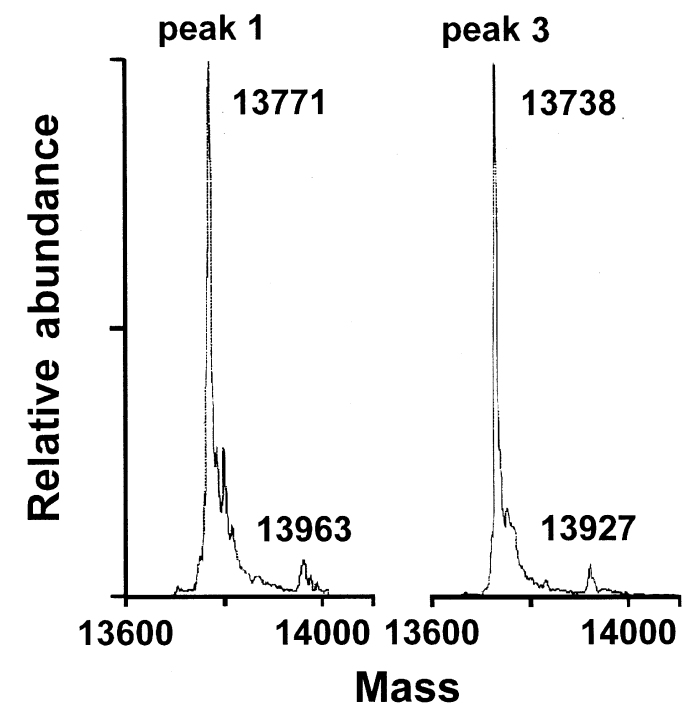

Fig. 6. HPLC purification and ESI-MS of NCS-modified CRV-W6D49. (A) After oxidative modification by NCS, CRV-W6D49 was fractionated by RP-HPLC on a C8 silica gel column. Peaks 1-3 were the differentially oxidized CRV-W6D49, peak 4 was the unmodified protein. (B) Transformed ESI-mass spectra of peaks 1 and 3, showing molecular masses which are consistent with those calculated for the $(\mathrm{MetO})_{6}$ and $(\mathrm{MetO})_{4}$ derivatives of CRV-W6D49, respectively. 


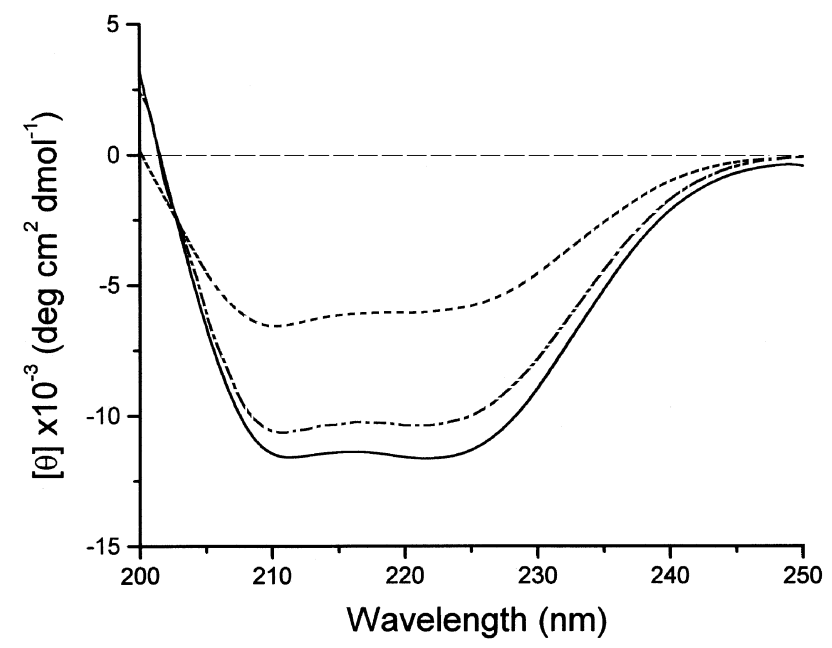

Fig. 7. CD spectra of the native and NCS-modified CRV-W6D49 derivatives. The spectra of the native (-), the NCS-oxidized CRV-W6D49 $(\mathrm{MetO})_{6}(--\cdot-)$ and $(\mathrm{MetO})_{4}(---)$ in $12 \mathrm{~mm}$ Tris/HCl buffer, $\mathrm{pH} 7.4$, with $2 \mathrm{mM} \mathrm{CaCl}_{2}$ at $25^{\circ} \mathrm{C}$.

four of the Met residues only slightly decreased, but oxidation of all the six Met residues of CRV-W6D49 greatly reduced its edema-inducing activity (Fig. 8). Thus, these Met residues are probably involved in the interactions between CRV-W6D49 and the target cells such as myocytes, neutrophils or polymorphonuclear leukocytes [18,28].

To conclude, this study has elucidated the structures and the activities of four $\mathrm{PLA}_{2} \mathrm{~S}$ present in the venom of a medically important pitviper C. rhodostoma. Acidic PLA $_{2}$ variants of this venom inhibit platelet aggregation and contribute to systemic bleeding, while the basic $\mathrm{PLA}_{2}$ homolog causes local myonecrosis and edema following the snakebites. This basic and Met-rich $\mathrm{PLA}_{2}$ homolog is more similar to the Lys 49-PLA 2 homolog than to other Asp 49-PLA 2 s, and therefore

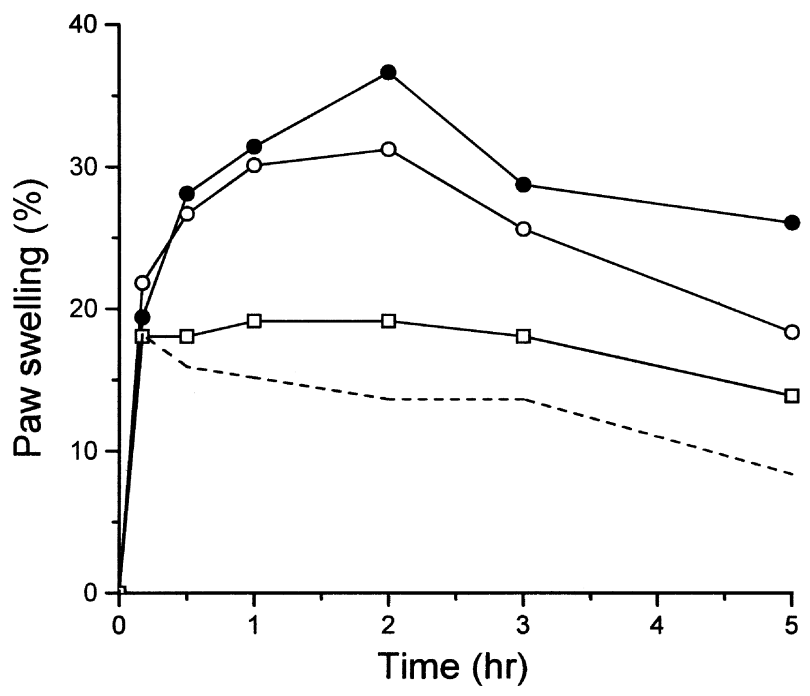

Fig. 8. Effect of chemical modification on the edema-inducing activity of CRV-W6D49. Time course of the edema induced by injecting the native $(\bullet)$, the NCS-oxidized CRV-W6D49 derivatives (MetO) 6 ( $\square$ ) and (MetO) 4 (O), and methylated-CRV-W6D49 to rat paws, and that of a control experiment (---), with injection of the same volume $(100 \mu \mathrm{L})$ of sterile $\mathrm{NaCl} / \mathrm{P}_{\mathrm{i}}$. The experiments were repeated twice and similar results were obtained. appears to be a novel type of venom PLA 2 . The cDNAs encoding six untranslated $C$. rhodostoma $\mathrm{PLA}_{2} \mathrm{~s}$ were also cloned, two of them are almost identical to those for the $\mathrm{PLA}_{2} \mathrm{~S}$ abundantly present in $T$. mucrosquamatus venom. Special features of the venom $\mathrm{PLA}_{2} \mathrm{~S}$ molecules of this monotypic pitviper were highlighted to testify the biodiversity of the pitviper venom $\mathrm{PLA}_{2} \mathrm{~S}$ and shed light on the evolutionary relationships between the Asian pitvipers.

\section{A C K N O WLED GEMENTS}

We thank our colleague Professor S. H. Wu for providing 3D modelling facilities, and Mr W. Z. Yang and Mr Y. F. Liew for analyses and cloning of some of the $\mathrm{PLA}_{2}$, and Dr Kay-Hooi Khoo for critical reading of the manuscript. This study is supported by research grants from the National Science Council and Academia Sinica, Taiwan.

\section{REFERENCES}

1. Tan, N.-H. \& Ponnudurai, G. (1996) The toxicology of Calloselasma rhodostoma (Malayan pit viper) venom. J. Toxicol.-Toxin Rev. 15, 1-17.

2. Wang, Y.-M., Liew, Y.-F., Chang, K.-Y. \& Tsai, I.-H. (1999) Purification and characterization of the venom phospholipase $\mathrm{A}_{2}$ from Asian monotypic Crotalinae snakes. J. Nat. Toxins 8, 331-340.

3. Danse, J.M., Gasparini, S. \& Menez, A. (1997) Molecular biology of snake venom phospholipases $\mathrm{A}_{2}$. In Venom Phospholipase $A_{2}$ Enzyme: Structure, Function and Mechanism. (Kini, R.M., ed.), pp. 29-71. J. Wiley \& Sons, UK.

4. Tsai, I.-H. (1997) Phospholipases $A_{2}$ of Asian snake venoms. J. Toxicol.Toxin Rev. 16, 79-114.

5. Ogawa, T., Wakashima, K.I., Nobuhisa, I., Deshimaru, M., Shimohigashi, Y., Fukumaki, Y., Sakaki, Y., Hattori, S. \& Ohno, M. (1996) Accelerated evolution of snake veom phospholipase $\mathrm{A}_{2}$ isozymes for acquisition of diverse physiological functions. Toxicon 34, 1229-1236.

6. Tsai, I.-H., Wang, Y.-M., Chiang, T.-Y., Chen, Y.-L. \& Huang, R.-J. (2000) Purification, cloning and sequence analyses for pro-metalloprotease-disintegrin varients from Deinagistrodon acutus venom and subclassification of the small venom metalloproteases. Eur. J. Biochem. 267, 1359-1367.

7. Cho, W.H., Markowitz, M.A. \& Ketzdy, F.J. (1988) A new class of phospholipase $\mathrm{A}_{2}$ substrates: kinetics of the phospholipase $\mathrm{A}_{2}$ catalyzed hydrolysis of 3-(acyloxy)-4-nitrobenzoic acids. J. Am., Chem. Soc. 110, 5166-5171.

8. Hunkapiller, M.W. \& Hood, L.E. (1983) Analysis of phenylthiohydantoins by ultrasensitive gradient high-performance liquid chromatography. Methods Enzymol. 91, 486-493.

9. Bradford, M.M. (1976) A rapid and sensitive method for the quantitation of microgram quantities of protein utilizing the principle of protein-dye binding. Anal. Biochem. 72, 248-254.

10. Tsai, I.-H., Lu, P.-J., Wang, Y.-M., Ho, C.-L. \& Liaw, L.-L. (1995) Molecular cloning and characterization of a neurotoxic phospholipase $\mathrm{A}_{2}$ from the venom of Taiwan habu (Trimeresurus mucrosquamatus). Biochem. J. 311, 895-900.

11. Jeng, T.W., Hendon, R.A. \& Fraenkel-Conrat, H. (1978) Search for relationships among the hemolytic, phospholipolytic and neurotoxic activities of snake venom. Proc. Natl Acad. Sci. USA 75, 600-604.

12. Au, L.-C., Chou, J.-S., Chang, K.-J., Teh, G.-W. \& Lin, S.-B. (1993) Nucleotide sequence of a full-length cDNA encoding a common precursor of platelet aggregation inhibitor and hemorrhagic protein from Calloselasma rhodostoma venom. Biochim. Biophys. Acta 1173, 243-245.

13. Maniatis, T., Fritsch, E.F. \& Sambrook, J. (1989) Molecular Cloning: a Laboratory Manual. Cold Spring Harbor Laboratory Press, Cold Spring Harbor, New York.

14. Shechter, Y., Burstein, Y. \& Gertler, A. (1977) Effect of oxidation of 
methionine residues in chicken ovomucoid on its inhibitory activities against trypsin, chymotrypsin, and elastase. Biochemistry 16, 992-997.

15. Boudier, C. \& Bieth, J.G. (1994) Oxidized mucus proteinase inhibitor: a fairly potent neutrophil elastase inhibitor. Biochem. $J$. 303, 61-68.

16. Verheij, H.M., Volwerk, J.J., Jansen, E.H., Puyk, W.C., Dijkstra, B.W., Drenth, J. \& de Haas, G.H. (1980) Methylation of histidine-48 in pancreatic phospholipase $\mathrm{A}_{2}$. Role of histidine and calcium ion in the catalytic mechanism. Biochemistry 19, 743-750.

17. Vyas, A.A., Pan, J.-J., Patel, H.V., Vyas, K.A., Chiang, C.-M., Sheu, Y.C., Hwang, J.-K. \& Wu, W.-G. (1997) Analysis of binding of cobra cardiotoxins to heparin reveals a new $\beta$-sheet heparin-binding structural motif. J. Biol. Chem. 272, 9661-9670.

18. Liu, C.-S., Chen, J.-M., Chang, C.-H., Chen, S.-W., Teng, C.-M. \& Tsai, I.-H. (1991) The amino acid sequence and properties of an edema-inducing Lys-49 phospholipase $\mathrm{A}_{2}$ homolog from the venom of Trimeresurus mucrosquamatus. Biochim. Biophys. Acta 1077, 362-370.

19. Jones, T.A., Zou, J.Y., Cowan, S.W. \& Kjeldgaard, M. (1991) Improved methods for building protein models in electron density maps and the location of errors in these models. Acta Crystallogr. A47, 110-119.

20. Scott, D.L., Achari, A., Vidal, J.C. \& Sigler, P.B. (1992) Crystallographic and biochemical studies of the (inactive) Lys-49 phospholipase $\mathrm{A}_{2}$ from the venom of Agkistridon piscivorus piscirorus. J. Biol. Chem. 267, 22645-22657.

21. Brunger, A.T. (1992) X-PLOR: a System for X-Ray Crystallography and NMR. Yale University Press, New Haven, USA.

22. Laskowski, R.A., MacArthur, M.W., Moss, D.S. \& Thronton, J.M. (1993) PROCHECK: a program to check the stereochemical quality of protein structures. J. Appl. Cryst. 26, 283-291.

23. Tsai, I.H., Murthy, S.N.P. \& Steck, T.L. (1982) Effect of red cell membrane binding on the catalytic activity of glyceraldehyde-3phosphate dehydrogenase. J. Biol. Chem. 257, 1438-1442.

24. Wang, X.-Q., Yang, J., Gui, L.-L., Lin, Z.-J., Chen, Y.-C. \& Zhou, Y.-C. (1996) Crystal structure of an acidic phospholipase $\mathrm{A}_{2}$ from the venom of Agkistrodon halys Pallas at $2.0 \AA$ resolution. J. Mol. Biol. 5, 669-676.

25. Ohno, M., Menez, R., Ogawa, T., Danse, J.M., Shimohigashi, Y., Fromen, C., Ducancel, F., Zinn-justin, S., Le Do, M.H., Boulain, J.-C., Tamiya, T. \& Menez, A. (1998) Molecular evolution of snake toxins: is the functional diversity of snake toxins associated with a mechanism of accelerated evolution? Prog. Nucleic Acid Res. Mol. Biol. 59, 307-364.

26. Selistre de Araujo, H.S., White, S.P. \& Ownby, C.L. (1996) Sequence analysis of Lys 49 phospholipase $\mathrm{A}_{2}$ myotoxins: a highly conserved class of proteins. Toxicon 34, 1237-1242.
27. Ward, R.J., Alves, A.R., Neto, J.K., Arni, R.K. \& Casari, G. (1998) A sequence space analysis of Lys-49 phospholipases $\mathrm{A}_{2}$ : clues towards identification of residues involved in a novel mechanism of membrane damage and in myotoxicity. Prot. Engineer. 11, 285-294.

28. Lomonte, B., Moreno, E., Tarkowski, A., Hanson, L.A. \& Maccarana, M. (1994) Neutralizing interaction between heparins and myotoxin II, a lysine 49 phospholipase $\mathrm{A}_{2}$ from Bothrops asper snake venom. J. Biol. Chem. 269, 29867-29873.

29. Wang, Y.-M., Wang, J.-H., Pan, F.-M. \& Tsai, I.-H. (1996) Lys-49 phospholipase $\mathrm{A}_{2}$ homologs from venoms of Deinagkistrodon acutus and Trimeresurus mucrosquamatus have identical protein sequence. Toxicon 34, 485-489.

30. Kini, R.M. \& Evan, H.J. (1995) A novel approach to the design of potent bioactive peptides by incorporation of proline brackets: antiplatelet effects of Arg-Gly-Asp peptides. FEBS Lett. 375, 15-17.

31. Pan, H., Liu, X.-L., Ou-Yang, L.-L., Yang, G.-Z., Zhou, Y.-C., Li, Z.-P. \& Wu, X.-F. (1998) Diversity of cDNAs encoding phospholipase $A_{2}$ from Agkistrodon halys Pallas venom, and its expression in E. coli. Toxicon 36, 1155-1163.

32. Liu, X.-L., Pan, H., Yang, G.-Z., Wu, S.-F. \& Zhou, Y.-C. (1999) Cloning, expression and biochemical characterization of a basicacidic hybrid phospholipase $\mathrm{A}_{2}$-II from Agkistrodon halys Pallas. Biochim. Biophys. Acta 1431, 157-165.

33. Liu, X.-L., Pan, H., Yang, G.-Z., Wu, S.-F. \& Zhou, Y.-C. (1999) Cloning and sequencing of genes encoding phospholipase $\mathrm{A}_{2}$ from Agkistrodon acutus. Acta Biochim. Biophys. Sinica (China) 31, 41-45.

34. John, T.R., Smith, L.A. \& Kaiser, I.I. (1994) Genomic sequences encoding the acidic and basic subunits of Mojave toxin: unusually high sequence identity of non-coding regions. Gene 139, 229.

35. Lindahl, U., Marion, K.G. \& Kjellen, L. (1998) Regulated diversity of heparan sulfate. J. Biol. Chem. 273, 24979-24982.

36. Gellman, S.H. (1991) On the role of methionine residues in the sequence-independent recognition of nonpolar protein surfaces. Biochemistry 30, 6633-6636.

37. Collaborative Computational Project, Number, 4. (1994) The CCP4 Suite: programs for protein crystallography. Acta Crystallogr. D50, 760-763.

38. Nicholls, A., Sharp, K.A. \& Honig, B. (1991) Protein folding and association: insights from the interfacial and thermodynamic properties of hydrocarbons. Proteins 11, 281-296.

39. Kraulis, P.J. (1991) MOLSCRIPT: a program to produce both detailed and schematic plots of protein structures. J. Appl. Cryst. 24, 946-950.

40. Merrit, E.A. \& Murphy, M.E.P. (1994) Raster3D, Version 2.0: a program for photorealistic molecular graphics. Acta Crystallogr. D50, 869-873. 